\title{
Genes predisposing to syndromic and nonsyndromic infertility: a narrative review
}

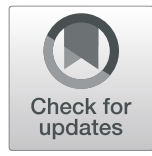

\author{
Tajudeen O. Yahaya ${ }^{1 *} \mathbb{D}$, Usman U. Liman², Haliru Abdullahi ${ }^{1}$, Yahuza S. Koko ${ }^{1}$, Samuel S. Ribah', \\ Zulkarnain Adamu ${ }^{1}$ and Suleiman Abubakar ${ }^{1}$
}

\begin{abstract}
Background: Advanced biological techniques have helped produce more insightful findings on the genetic etiology of infertility that may lead to better management of the condition. This review provides an update on genes predisposing to syndromic and nonsyndromic infertility.

Main body: The review identified 65 genes linked with infertility and infertility-related disorders. These genes regulate fertility. However, mutational loss of the functions of the genes predisposes to infertility. Twenty-three (23) genes representing 35\% were linked with syndromic infertility, while 42 genes (65\%) cause nonsyndromic infertility. Of the 42 nonsyndromic genes, 26 predispose to spermatogenic failure and sperm morphological abnormalities, 11 cause ovarian failures, and 5 cause sex reversal and puberty delay. Overall, 31 genes (48\%) predispose to male infertility, 15 genes (23\%) cause female infertility, and 19 genes (29\%) predispose to both. The common feature of male infertility was spermatogenic failure and sperm morphology abnormalities, while ovarian failure has been the most frequently reported among infertile females. The mechanisms leading to these pathologies are gene-specific, which, if targeted in the affected, may lead to improved treatment.
\end{abstract}

Conclusions: Mutational loss of the functions of some genes involved in the development and maintenance of fertility may predispose to syndromic or nonsyndromic infertility via gene-specific mechanisms. A treatment procedure that targets the affected gene(s) in individuals expressing infertility may lead to improved treatment.

Keywords: Genes, Infertility, Mutation, Ovarian Failure, Syndrome

\section{Background}

Infertility is generally defined as the inability of an organism to reproduce naturally. In humans, it is complex and defined as the failure to conceive after a year of regular and unprotected sexual intercourse [1]. Infertility affects about 48.5 million couples, representing $15 \%$ of couples worldwide [2]. Males are responsible for $20-30 \%$ of infertility, while females account for $20-35 \%$, and the remaining is shared by both $[2,3]$. However, the prevalence of infertility varies worldwide, being highest in South East Asia and West Africa $[4,5]$.

\footnotetext{
* Correspondence: yahaya.tajudeen@fubk.edu.ng; yahayatajudeen@gmail.com 'Department of Biolog, Federal University Birnin-Kebbi, PMB 1157, Birnin-Kebbi, Nigeria

Full list of author information is available at the end of the article
}

Infertility causes psychological, economic, and health burdens, resulting in trauma and stress, particularly in societies that emphasize childbearing [6]. In some parts of the world such as Africa and Asia, infertile couples, particularly women, face stigmatization, discrimination, and divorce. A variety of pathologies are suspected in infertility, which includes endocrine dysfunction, genetic abnormalities, infection and diseases, and autoimmune disorders $[7,8]$. These pathologies are triggered by environmental factors, including toxic substance exposure as well as lifestyles, such as delayed marriage, nutrition, obesity, stress, smoking, drug use, and alcohol consumption [9]. An in-depth understanding of these mentioned causes is necessary for the prevention and effective treatment of infertility [7]. The genetic causes, in particular, need more attention and understanding because it

\section{Springer Open}

(c) The Author(s). 2020 Open Access This article is licensed under a Creative Commons Attribution 4.0 International License, which permits use, sharing, adaptation, distribution and reproduction in any medium or format, as long as you give appropriate credit to the original author(s) and the source, provide a link to the Creative Commons licence, and indicate if changes were made. The images or other third party material in this article are included in the article's Creative Commons licence, unless indicated otherwise in a credit line to the material. If material is not included in the article's Creative Commons licence and your intended use is not permitted by statutory regulation or exceeds the permitted use, you will need to obtain permission directly from the copyright holder. To view a copy of this licence, visit http://creativecommons.org/licenses/by/4.0/. 
accounts for $15-30 \%$ of male infertility alone $[10,11]$. Fortunately, in the last few decades, technological innovations in biological studies have made possible more insightful findings on the genetic etiology of infertility that may lead to better treatment. This review, therefore, provides an update on genetics and pathophysiology of syndromic and nonsyndromic infertility.

\section{Main text}

\section{Database searching and search strategy}

To identify relevant papers on the topic, academic databases such as PubMed, Google Scholar, Uniport, GeneCards, Genetics Home Reference (GHR), and National Center for Biotechnology Information (NCBI) were searched. Key search words used include 'infertility', 'male infertility', 'female infertility', 'etiology of infertility', and 'causes of infertility'. Others are 'genetic etiology of infertility', 'gene mutations predisposing to infertility', 'syndromic and nonsyndromic infertility', and 'gene mutations causing infertility'. Each database was searched independently, after which the articles retrieved were pooled together and double citations removed.

\section{Inclusion and exclusion criteria}

Articles were included if they are available in the English language, focused on infertility, genetic etiology of infertility, and pathophysiology of infertility. Studies published before the year 2000 were excluded, except sometimes in which the information was vital. This was done to ensure up-to-date information.

A total of 133 articles were identified from all the databases, of which 120 were retained after removing duplicates (Fig. 1). Of the 120 articles retained, 110 passed the relevance test for eligibility. From the eligibility test, 101 articles fit the study objectives and were reviewed and included in this study.

\section{Genes predisposing to syndromic and nonsyndromic infertility}

The searches identified several gene mutations linked with infertility and infertility-related disorders and syndromes. However, it is beyond this study to discuss all the genes. As such, 65 genes frequently encountered in our searches and with sufficient information were included in this study. The genes were classified into genes predisposing to syndromic infertility, genes predisposing to nonsyndromic spermatogenic failure and sperm morphology abnormalities, genes predisposing to nonsyndromic sex reversal and pubertal delay, and genes predisposing to nonsyndromic ovarian failure.

\section{Genes predisposing to syndromic infertility}

Twenty-three (23) genes, representing $35 \%$ of the total genes collected, were linked with syndromic

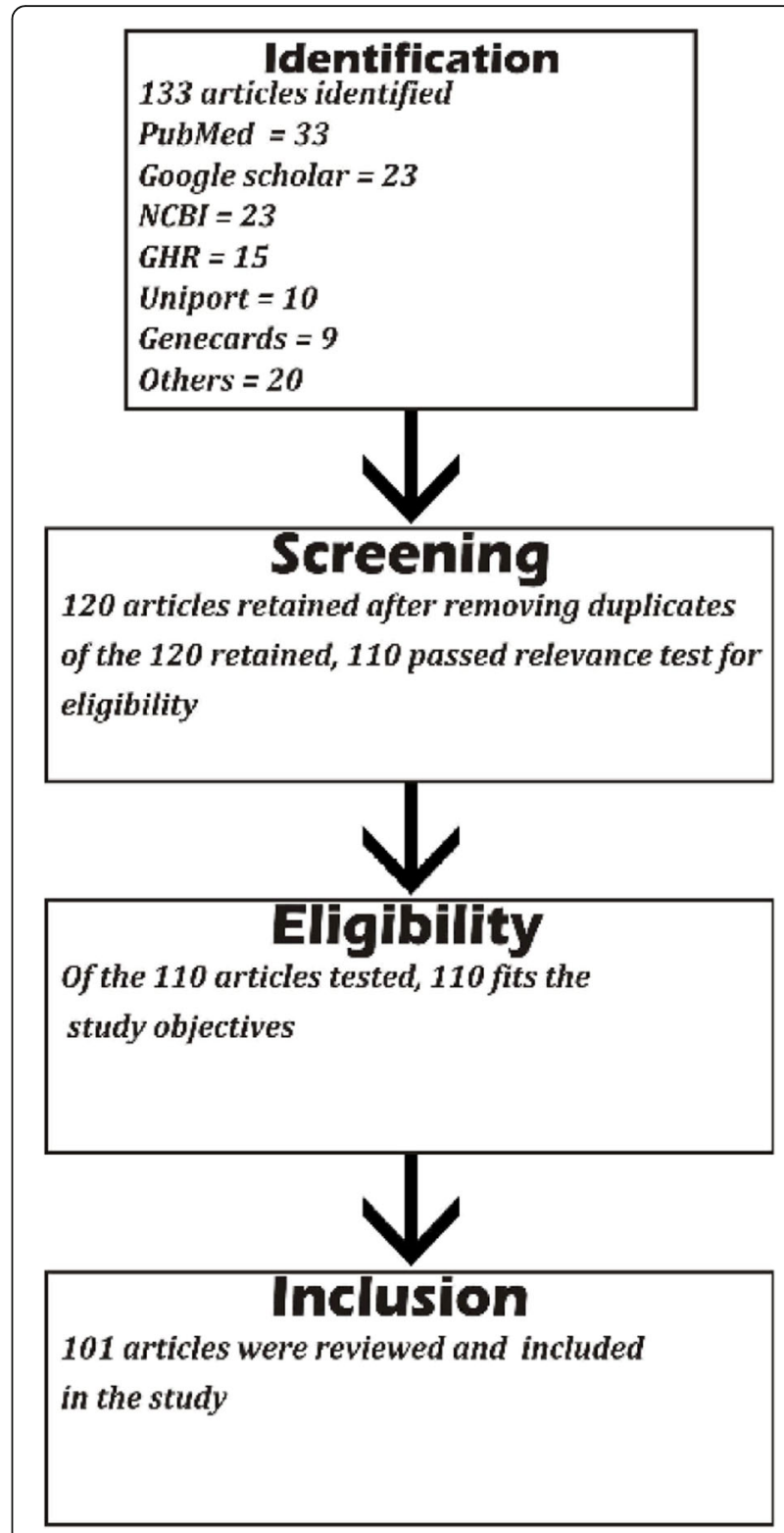

Fig. 1 Article selection flow diagram

infertility (Table 1). The most common syndromes associated with infertility identified by this study are polycystic ovary syndrome (PCOS), Swyer syndrome, and Sertoli cell-only syndrome, respectively. Others include the congenital bilateral absence of the vas deferens (CBAVD), Wilm's tumour, fibroid, Kallmann syndrome, Frasier syndrome, Denys-Drash syndrome, and Bordet-Biedl syndrome. Most of the genes cause female infertility with features such as hypogonadotropic hypogonadism, ovarian failure, sex reversal, gonad underdevelopment, puberty delay, and menstrual disorders. Some genes also predispose to male 
Table 1 Genes predisposing to syndromic infertility

\begin{tabular}{|c|c|c|c|c|}
\hline Gene & Locus & Biological functions & Some mutations reported & Pathophysiology/disorders \\
\hline $\begin{array}{l}\text { CFTR (cystic fibrosis } \\
\text { transmembrane } \\
\text { conductance regulator) }\end{array}$ & $7 q 31.2$ & $\begin{array}{l}\text { CFTR transports chloride ions into and } \\
\text { out of cells, controlling the movement } \\
\text { of water in tissues, which is necessary } \\
\text { for the production of mucus that } \\
\text { lubricates and protects the lining of the } \\
\text { airways, digestive system, reproductive } \\
\text { system, and other organs and tissues } \\
\text { [12]. }\end{array}$ & $\begin{array}{l}\text { A 3-bp deletion named F508del, } 5 \text { T sin- } \\
\text { gle nucleotide polymorphism (SNP) } \\
\text { within intron } 8,7 \text { T SNP within intron } 8 \text {, } \\
\text { and missense mutation named R117H } \\
\text { within exon } 4 \text { were reported [13]. } \\
\text { Others are G542X, G551D, R553X, } \\
\text { W1282X, and N1303K }[13,14] .\end{array}$ & $\begin{array}{l}\text { It causes CBAVD, which causes a } \\
\text { disconnection between the } \\
\text { epididymis and the ejaculatory duct, } \\
\text { leading to obstructive azoospermia } \\
\text { [13]. Also causes cystic fibrosis (CF), } \\
\text { which is associated with menstrual } \\
\text { irregularities, including amenorrhea, } \\
\text { irregular cycles, and anovulation [15]. }\end{array}$ \\
\hline
\end{tabular}

NR5A1 (nuclear receptor subfamily 5

9q33.3 NR5A1 produces a transcription factor group A member 1)

WT1 (Wilms' tumor 1)

The gene is a transcription factor that is expressed in the kidneys, ovaries, and testes [20] and functions in gonadogenesis. Particularly, it plays an active role in ovarian follicle development [21] and spermatogenesis [22].

FMR1 (fragile $X$ mental $\mathrm{Xq} 27.3$ retardation 1)

GALT (galactose-1phosphate uridylyltransferase)

GDF9 (growth/ differentiation factor 9 ) $5 q 31.1$

9p13.3 The gene synthesizes galactose-1phosphate uridylyltransferase, which converts galactose obtained from food into glucose, the main fuel for all cellular activities. This chemical reaction also produces an active form of galactose known as UDP-galactose, which is used to build galactose-containing proteins and fats, both which are involved in energy production, chemical signaling, cell structure building, and molecule transport [28].

This gene encodes a transforming growth factor-beta superfamily, which is necessary for ovarian folliculogenesis and somatic cell function $[30,31]$.
A missense heterozygous mutation involving $c$. $3 G \rightarrow A$ transition and two heterozygous frameshift mutations named c. 666delC and c. 390delG were reported [17]. The following were also reported: p. Pro311Leu, p. Arg191Cys, p. Gly121Ser, p. Asp238Asn, and p. Gly123Ala/p. Pro129Leu [18], as well as a heterozygous mutation named c. $195 \mathrm{G}$ $>A[19]$.

A heterozygous point mutation in intron 7 named $+2, T \rightarrow G$ was reported [23]. R362Q and K386R missense mutations among Chinese population [22].

Moreover, Seabra et al. [24] reported $p$. Pro130Leu and pCys350Arg missense mutations among Portuguese. Two heterozygous missense mutations named $p$. Pro126Ser in exon 1 and $p$. Arg370His in exon7 were also reported among the Chinese women [25]. A variant named $I V S+4 C>T$ has also been reported [20].

A region of the gene contains a CGG trinucleotide repeat of less than 10 to about 40. However, the FMR1 mutation has been reported in which the CGG was abnormally repeated from 200 to more than 1000 times [26]

The SNP called Gln188Arg or Q188R is prevalent among white Europeans and North Americans [28]. Another SNP called Ser135Leu or \$135L are found mostly among the African descent [28] The SNP named Asn314Asp or N314D was also reported [28].

Several missense mutations reported [32].

Predisposes to Swyer syndrome, which disrupts sexual differentiation and prevents affected 46, XY male from developing testes and causing them to develop a uterus and fallopian tubes [16]. Because of the lack of development of the gonads, Swyer syndrome is also called $46, X Y$ complete gonadal dysgenesis. In females, mutations in the gene cause several ovarian anomalies, including 46, XX gonadal dysgenesis [16].

The $+2, T \rightarrow G$ mutation causes Wilms' tumor, characterized by congenital male genitourinary malformation [23]. R362Q and K386R missense mutations cause loss of function of the WT1 protein, resulting in non-obstructive azoospermia [22]. The $p$. Pro126Ser and p. Arg370His missense mutations cause premature ovarian follicles (POF) [25]. Some mutations also cause Frasier syndrome and Denys-Drash syndrome, both of which often affect the male kidney and genitalia development [20].

Abnormal CGG expansion causes instability in the region, deactivating the gene and making little or no protein, resulting in a condition called fragile $X$ syndrome characterized mainly by mental retardation [26]. CGG elongation between 55 and 200 repeats causes POF [27] and fragile $X$-associated primary ovarian insufficiency (FXPOI) [26]. FXPOI is characterized by irregular menstrual cycles, early menopause, and elevated levels of folliclestimulating hormone (FSH) [26].

t represses or stops the activity of the galactose-1-phosphate uridylyltransferase, preventing cells from converting galactose into glucose. Consequently, galactose-1-phosphate and related compounds build up to toxic levels in the body, damaging tissues and organs, and leading to a condition known as galactosemia [28]. Women with galactosemia express hypergonadotropic hypogonadism and secondary amenorrhea [29], as well as ovarian failure [30].

t elevates the levels of serum gonadotropins and reduces estradiol, predisposing to premature ovarian failure 14 (POF14), an ovarian disorder defined as the cessation of ovarian function under the age of 40 years. The condition is characterized by oligomenorrhea or amenorrhea 
Table 1 Genes predisposing to syndromic infertility (Continued)

\begin{tabular}{lll}
\hline Gene & Locus & Biological functions \\
\hline & \\
& \\
MED12 (mediator & Xq13.1 & The MED12 gene codes for a protein \\
complex subunit 12) & called mediator complex subunit 12, \\
& which regulates gene activity by linking \\
& transcription factors with an enzyme \\
& called RNA polymerase II. The MED12 \\
& protein is involved in several chemical \\
& signaling pathways that control many \\
& cellular activities, such as cell growth, \\
& cell movement, and cell differentiation \\
& [34].
\end{tabular}

ANOS1 (anosmin 1)/ KAL1

LEP (leptin)

$7 \mathrm{q} 32$.
Xp22.31 The gene encodes a protein called anosmin-1, which is involved in embryexpressed in the brain and involved in the migration of neurons that produce gonadotropin-releasing hormone $(\mathrm{GnRH})$, which controls the production of several hormones that direct sexual development before birth and during puberty, such as the ovaries and testes functions [35].

Some mutations reported

Several somatic mutations in the MED12 gene have been reported [34].
The gene codes for leptin, which is a hormone that takes part in body weigh regulation [37], metabolism, and puberty [38], as well as cell signaling that regulates sex development hormones [37]. onic development. Anosmin-1 is

Mutations that delete a part or the entire gene, as well as SNPs that alter or change amino acids in anosmin-1, have been reported [35], among which is c. $1267 C>T[36]$

Complete deletion of the gene has been reported in infertile humans and rats [38]. A SNP named rs 10244329 was also reported [39].

At least 18 LEPR gene mutations have been reported [40]. leptin receptor, which is embedded in many tissues, including the hypothalamus, and helps regulate body weight by providing binding sites for leptin [40].
NROB1 (nuclear receptor subfamily 0 group B member 1)/ AHC (adrenal hypoplasia congenital)
Xp21.2 The NROB1 gene codes for a transcription factor called DAX1, which is involved in the development and function of several hormone-producing (endocrine) tissues, including the adrenal glands, hypothalamus, pituitary gland, as well as the ovaries and testes [41]. 3p14.3 The HESX1 gene encodes a transcription factor that regulates the early embryonic development of several body structures, particularly the pituitary
Complete and partial deletions of the gene have been reported [41]. Abnormally short versions of the DAX1 protein as well as SNPs have also been reported [41].

SNPs as well as insertion and deletion mutations have been reported in this gene [42].
Pathophysiology/disorders

[33]. Altered expression of the gene is also associated with polycystic ovary syndrome (POS) [31].

It causes uterine leiomyomas, which are noncancerous growths also known as uterine fibroids. Uterine leiomyomas are common among adult women and cause pelvic pain abnormal bleeding, and, in some cases, infertility [34]. MED12 mutations produce nonfunctional protein, which disrupts normal cell signaling and impairs regulation of cell growth and other cell functions. As a result, certain cells divide uncontrollably, leading to the growth of a tumor [34].

Alters the synthesis or function of anosmin-1 during embryonic development, resulting in the loss of sense of smell and the production of sex hormone, respectively, and the latter interferes with normal sexual development causing absence or delay of puberty [35]. Mutations in the gene also predispose to Kallmann syndrome, a disorder characterized by hypogonadotropic hypogonadism [35]. Males expressing hypogonadotropic hypogonadism often have an unusually small penis (micropenis), undescended testes, and lack of secondary sex characteristic, while females fail to menstruate and develop breast [35].

Causes congenital leptin deficiency, a disorder that causes the absence of leptin, resulting in the loss of signaling that triggers feelings of satiety, leading to excessive hunger and weight gain, reduced production of hormones that direct sexual development, and ultimately ending in hypogonadotropic hypogonadism [37].

Results in less receptor protein reaching the cell surface, causing a condition called leptin receptor deficiency, which reduces $L E P R$ protein binding and signaling activities as well as satiety, resulting in excessive hunger and weight and reduced sex hormones, culminating in hypogonadotropic hypogonadism [40].

Produces inactive DAX1 protein, disrupting normal development and function of hormone-producing tissues, particularly the adrenal glands, hypothalamus, pituitary, and gonads, resulting in a condition called $\mathrm{X}$ linked adrenal hypoplasia congenital [41], characterized by male puberty delay [38]. Mutations in this gene also cause Swyer syndrome [41].

Alters the function of the HESX protein and represses the activity of other genes, disrupting the formation and early development of the 
Table 1 Genes predisposing to syndromic infertility (Continued)

\begin{tabular}{|c|c|c|c|c|}
\hline Gene & Locus & Biological functions & Some mutations reported & Pathophysiology/disorders \\
\hline & & gland [42]. & & $\begin{array}{l}\text { pituitary gland, optic nerves, and } \\
\text { other brain structures, resulting in } \\
\text { gonadotropin deficiency and a } \\
\text { condition known as septo-optic dys- } \\
\text { plasia [42]. Septo-optic dysplasia is } \\
\text { characterized by hypogonadotropic } \\
\text { hypogonadism [38]. }\end{array}$ \\
\hline $\begin{array}{l}\text { LHß (luteinizing } \\
\text { hormone beta-subunit) }\end{array}$ & $19 q 13.33$ & $\begin{array}{l}\text { It encodes the beta subunit of } \\
\text { luteinizing hormone }(\mathrm{LH}) \text {, which is } \\
\text { expressed in the pituitary gland and } \\
\text { promotes spermatogenesis and } \\
\text { ovulation by stimulating the testes and } \\
\text { ovaries to synthesize steroids [43]. }\end{array}$ & $\begin{array}{l}\text { The SNP named G1052A has been } \\
\text { reported [44]. Six other SNPs were also } \\
\text { identified and are gC356090A, } \\
\text { gC356113T, gA356701G, gG355869A, } \\
\text { gG356330C, and gG356606T [45]. }\end{array}$ & $\begin{array}{l}\text { Causes defective LH, leading to low } \\
\text { testosterone and gonadotropins, } \\
\text { culminating in pubertal delay, } \\
\text { bilaterally small descended testes, } \\
\text { and infertility [38]. Also increases } \\
\text { susceptibility to PCOS, characterized } \\
\text { by pubertal delay [38]. }\end{array}$ \\
\hline
\end{tabular}

LHCGR (luteinizing

hormone/

choriogonadotropin

receptor)
$2 p 16.3 \quad$ The gene synthesizes the luteinizing hormone/chorionic gonadotropin receptor which is a receptor for luteinizing hormone and chorionic gonadotropin. In males, chorionic gonadotropin stimulates the development of Leydig cells in the testis, which are also stimulated by luteinizing hormone to produce androgens, such as testosterone that controls male sexual development and reproduction. In females, luteinizing hormone triggers ovulation, while chorionic gonadotropins ensure normal progression of pregnancy [46].

$A R$ (androgen receptor) $\quad \mathrm{Xq12} \quad$ The $A R$ gene produces an androgen receptor, which is expressed in many tissues, where it binds to androgen to form an androgen-receptor complex, which in turn binds to DNA and regulates the activity of certain genes involved in male sexual development [47].

SRY (sex-determining

Yp11.2 The gene encodes a transcription factor region $Y)$

VDR (vitamin D receptor) 12q13.11 The gene is expressed in male and female reproductive tissues [49] and synthesizes a protein called vitamin D receptor, which forms a complex with an active form of vitamin $D$, known as calcitriol, and another protein called retinoid $X$ receptor, which then binds to particular regions of DNA, where it that control several processes, particularly calcium and phosphate absorption [50]. In mice, VDR signaling plays a role in folliculogenesis and fertility [51].

6p21.3 The gene encodes FKBP52, which plays an important role in potentiating regulates the activity of some genes
A SNP called G935A has been reported [44]. At least 17 other SNPs were reported [46].

Abnormal elongation of a DNA segment in the $A R$ gene known as $C A G$ which is normally repeated between less than 10 and 36, has been reported [47]. Some SNPs, as well as deletions and insertions, were also reported [47].
Impairs the development of LHCGR protein, preventing chorionic gonadotropin binding, and resulting in the absence, or poorly developed Leydig cells, a condition called Leydig cell hypoplasia, characterized by low testosterone, which interferes with male sexual development before and after birth [46]. Extreme Leydig cell hypoplasia causes $46, X Y$ male to develop female external genitalia and small undescended testes [46]. Mild Leydig cell hypoplasia results in an external genital that is not clearly male or female [46]. Mutations in the gene also cause polycystic ovary syndrome (POS) [46].

Results in the receptors that are unable to bind androgens or DNA, causing androgen insensitivity syndrome (AIS), a condition that causes male sexual dysfunction before birth and at puberty. The condition also causes $46, X Y$ male sex reversal also known as gonadal dysgenesis [47]. Mutations in the gene also cause polycystic ovary syndrome [47].

Prevents production of SRY protein or hampers it, resulting in Swyer syndrome, characterized by $46, X Y$ male sex reversal [48]. Sometimes the mutation may misplace the gene on the $X$ chromosome from the father, causing 46 , XX female to develop both ovarian and testicular tissues, a condition called ovotesticular disorder [48].

The SNP in exon 9 named rs 731236 was reported by Bagheri et al. [52].

Szczepańsk et al. [53] also reported two SNPs named rs 1544410 and rs222857.

Reduces follicle number, resulting in PCOS [51, 52] or endometriosisassociated infertility [53]. VDR knockout in female mice disrupts VDR signaling and ovarian response to stimulation, causing defective folliculogenesis and infertility [51]. Male mice deficient of VDR showed gonadal insufficiency and decreased sperm count and motility as well as histological abnormalities of the testis [49].

Deletions and two SNPs, known as Causes azoospermia [54] as well as rs2968909 and rs4409904, were reported implantation failure and recurrent 
Table 1 Genes predisposing to syndromic infertility (Continued)

\begin{tabular}{|c|c|c|c|c|}
\hline Gene & Locus & Biological functions & Some mutations reported & Pathophysiology/disorders \\
\hline & & $\begin{array}{l}\text { androgen receptor }(A R) \text { signaling in the } \\
\text { prostate and accessory glands [54]. }\end{array}$ & [55]. & $\begin{array}{l}\text { pregnancy [56]. Also predisposes to } \\
\text { PCOS [55]. }\end{array}$ \\
\hline $\begin{array}{l}\text { DBY (DEAD-box Y RNA } \\
\text { helicase)/DDX3Y } \\
\text { (DEAD-box helicase } 3 \\
\text { Y-linked) }\end{array}$ & Yq11.21 & $\begin{array}{l}\text { The gene resides in the AZFa region on } \\
\text { the Y chromosome and is expressed in } \\
\text { many tissues, but mostly in the } \\
\text { spermatogonia of the testis tissue and } \\
\text { translated only in the male germline } \\
\text { [57]. }\end{array}$ & Deletion mutations were reported [57]. & $\begin{array}{l}\text { Causes severe testicular pathology } \\
\text { known as Sertoli cell-only (SCO) syn- } \\
\text { drome, a condition that disrupts } \\
\text { spermatogenesis [57]. }\end{array}$ \\
\hline $\begin{array}{l}\text { USP9Y (ubiquitin } \\
\text { specific peptidase } 9 \text { Y- } \\
\text { linked) }\end{array}$ & Yq11.221 & $\begin{array}{l}\text { USP9Y resides in the azoospermia factor } \\
\text { a (AZFa) region of the Y chromosome } \\
\text { and encodes an enzyme called } \\
\text { ubiquitin-specific peptidase } 9, \text { Y-linked, } \\
\text { which is necessary for sperm production } \\
\text { [58]. }\end{array}$ & $\begin{array}{l}\text { AZFa deletions resulting in complete } \\
\text { loss of USP9Y have been reported [59]. }\end{array}$ & $\begin{array}{l}\text { Predisposes to Sertoli cell-only syn- } \\
\text { drome, characterized by the absence } \\
\text { of germ cells in the seminiferous tu- } \\
\text { bules, leading to azoospermia [59]. } \\
\text { Also causes spermatogenic failure Y- } \\
\text { linked } 2 \text { (SPGFY2), resulting in azoo- } \\
\text { spermia or oligozoospermia [59]. }\end{array}$ \\
\hline PLK4 (Polo-like kinase 4) & $4 q 28.1$ & $\begin{array}{l}\text { PLK4 protein resides in the centrioles } \\
\text { and plays an active role in centriolar } \\
\text { duplication that is necessary for normal } \\
\text { cell division }[60,61] \text {. }\end{array}$ & $\begin{array}{l}\text { A heterozygous mutation called } \\
\text { p.lle242Asn was observed in mice [62]. A } \\
\text { heterozygous } 13 \text { bp deletion called } \\
\text { c.201_213delGAAACATCCTTCT was also } \\
\text { reported [62]. }\end{array}$ & $\begin{array}{l}\text { Causes mitotic error in mice, resulting } \\
\text { in patchy germ cell loss in the testes } \\
\text { similar to the human Sertoli cell-only } \\
\text { syndrome (SCOS) }[62,63] \text {. }\end{array}$ \\
\hline $\begin{array}{l}\text { BBS9 (Bardet-Biedl } \\
\text { syndrome 9) } \\
\text { PTHB1 (parathyroid } \\
\text { hormone responsive- } \\
\text { B1) }\end{array}$ & 7p14 & $\begin{array}{l}\text { The specific role of the protein released } \\
\text { by this gene has not been determined } \\
\text { [64]. }\end{array}$ & $\begin{array}{l}\text { A haplotype named GAAAG as well as } \\
\text { three SNPs named rs3884597, rs6944723, } \\
\text { and rs } 11773504 \text { were reported [65]. }\end{array}$ & $\begin{array}{l}\text { Causes Bardet-Biedl syndrome, char- } \\
\text { acterized by many features, including } \\
\text { POF [65]. }\end{array}$ \\
\hline $\begin{array}{l}\text { FSHR (follicle- } \\
\text { stimulating hormone } \\
\text { receptor) }\end{array}$ & $2 \mathrm{p} 16.3$ & $\begin{array}{l}\text { The gene secretes a receptor for the } \\
\text { follicle-stimulating hormone, which } \\
\text { functions in the ovary and testis devel- } \\
\text { opment [66]. }\end{array}$ & $\begin{array}{l}\text { A SNP in exon } 7 \text { named C } 566 T \text { and } \\
\text { involving Ala to Val substitution at } \\
\text { residue } 189 \text { was reported by Aittomäk } \\
\text { [67]. }\end{array}$ & $\begin{array}{l}\text { Predisposes to ovarian dysgenesis } 1 \\
\text { (ODG1), characterized by primary } \\
\text { amenorrhea, poorly developed streak } \\
\text { ovaries, and high serum levels of FSH } \\
\text { and LH. May also cause ovarian } \\
\text { hyperstimulation syndrome (OHSS), } \\
\text { characterized by massive ovarian } \\
\text { enlargement as well as multiple } \\
\text { serous and hemorrhagic follicular } \\
\text { cysts lined by luteinized cells [68]. }\end{array}$ \\
\hline
\end{tabular}

infertility with phenotypic presentations, including hypogonadotropic hypogonadism, sex reversal, puberty delay or absence, gonad underdevelopment, and spermatogenic failure.

\section{Genes predisposing to nonsyndromic spermatogenic failure and sperm morphology abnormalities}

Twenty-six (26) genes, representing $40 \%$ of the total genes collected, predispose to nonsyndromic spermatogenic failure and sperm morphology abnormalities (Table 2). Most often, mutations in the genes cause meiotic arrest, resulting in acrosome malformation or absence, ultimately ending in sperm head abnormalities such as azoospermia, globozoospermia, oligospermia, and oligozoospermia. In some cases, the meiotic arrest may result in polyploidy spermatozoa, characterized by an enlarged sperm cell head called macrozoospermia. A meiotic arrest may also decrease sperm motility and hyperactivation needed to push spermatozoa through the uterus. Sometimes, mutations in the genes may cause chromatin damage or DNA fragmentation, disrupting spermatogenesis and causing sperm cell structural defects and loss.

\section{Genes predisposing to nonsyndromic sex reversal and pubertal delay}

Five (5) of the genes collected, representing $7.69 \%$ of the total genes, predispose to sex reversal and puberty delay or absence (Table 3). Most mutations in the genes cause reduced circulating levels of gonadotropins and testosterone, resulting in hypogonadotropic hypogonadism, characterized by the absence or incomplete sexual maturation. Mutations in the genes may also cause complete or partial gonadal dysgenesis, characterized by underdeveloped or presence of both gonads.

\section{Genes predisposing to nonsyndromic ovarian failure}

Eleven (11) of the genes collected, representing $16.92 \%$ of the total genes, predispose to nonsyndromic ovarian failure (Table 4). Some mutations in the genes may reduce the sensitivity of fully grown immature oocytes to progestin hormone, resulting in a reduced number of 
Table 2 Genes predisposing to nonsyndromic spermatogenic failure and sperm morphological abnormalities

SPATA16 (spermatogenesisassociated 16, also known as NYDSP12)

AURKC (aurora kinase C)

CATSPER (cation channel sperm associated 1)

MTHFR

(methylenetetrahydrofolatereductase)

SYCP3 (synaptonemal complex protein 3) 19q13.43 The AURKC codes for a protein called aurora kinase, which helps dividing cells separate from each other and ensures the accurate distribution of genetic materials (chromosomes). Aurora kinase C is most abundant in male testes, where it regulates the division of sperm cells, ensuring that every new sperm cell divides accurately and contains one copy of each chromosome [72].

11q13.1 The gene encodes a protein localized in the tail of sperm cells and transport calcium cations into the cells for norma sperm motility and a type of sperm cell motility called hyperactivation, which is a rigorous movement necessary to push the sperm cells through the cell membrane of the egg cell during fertilization [73].

1p36.22 The MTHFR gene synthesizes an enzyme called methylenetetrahydrofolate reductase, which converts a form of folate called 5,10 methylenetetrahydrofolate to an another form called 5methyltetrahydrofolate. The latter is the primary form of folate in the blood, where it helps converts the amino acid homocysteine to another amino acid called methionine. The body uses methionine to make proteins and other important compound as well as vital in DNA methylation and spermatogenesis $[75,76]$.

12q23.2 SYCP3 is embedded in the testis and encoded an essential structural component of the synaptonemal complex, which is involved in synapsis, recombination, and segregation of meiotic chromosomes [79].
Two insertion mutations named C.539-540insT and c.948949insATGGC, leading to frameshifts and premature stop codons known as p.Lys 180LysfSX8 and p.Asp317Metfs X18, have been reported [74]

A SNP named $677 C / T$ and involving the substitution of an alanine for a valine is the most common in infertile men with MTHFR deficiency [13]. The second mutation involved an $A$ to $C$ transition at nucleotide 1298 (A1298C), resulting in glutamate to alanine substitution in the MTHFR protein [77].

A heterozygous deletion called 643delA, and a heterozygous genetic change known as T657C was identified among Iranian women with recurrent pregnancy losses [17].
Causes acrosome malformation which can be absent in severe cases, resulting in sperm head abnormality characterized by round-headed sperms known as globozoospermia [71]. Also predisposes spermatogenic failure 6 (SPGF6), an infertility disorder caused by spermatogenesis defects [70].

Produces a nonfunctional aurora kinase $\mathrm{C}$ or a protein that breaks down quickly, preventing sperm cell division. Consequently, the sperm cells carry extra chromosomes (polyploidy spermatozoa), usually four copies of each instead of the usual one. The increase in chromosome number enlarges the sperm cell head and leads to the presence of multiple tails (flagella), a condition called macrozoospermia. The additional genetic materials may prevent any of the sperm cells from fusing with an egg or may result in miscarriage [72].

Alters or malfunctions CATSPER 1 protein or produces a protein that is degraded quickly by the cell. This impairs calcium entry into the sperm cell, decreasing the motility and preventing hyperactivation, ultimately resulting in CATSPER7-related non-syndromic male infertility. Affected men may also produce a smaller than the usual number of sperm cells or sperm cells that are abnormally shaped [73].

Loss of MTHFR decreases the activity of its enzyme, disrupting folic acid metabolism, resulting in DNA hypo-methylation, ultimately ending in the absence of germinal cells and spermatogenesis arrest $[13,75,78]$.

Causes early meiotic arrest, disrupting the spermatogenic process in males [17], resulting in spermatogenic failure 4 (SPGF4), a disorder characterized by azoospermia. In females, early meiotic arrest 
Table 2 Genes predisposing to nonsyndromic spermatogenic failure and sperm morphological abnormalities (Continued)

\begin{tabular}{|c|c|c|}
\hline & & $\begin{array}{l}\text { The gene ensures centromere } \\
\text { pairing during meiosis in male } \\
\text { germ cells, thus important for } \\
\text { normal spermatogenesis [80]. }\end{array}$ \\
\hline $\begin{array}{l}\text { HSF2 (heat-shock transcription factor } \\
\text { 2) }\end{array}$ & $6 q 22.31$ & $\begin{array}{l}\text { HSF2 is expressed in the testis } \\
\text { and encodes heat-shock tran- } \\
\text { scription factor 2, which binds } \\
\text { specifically to the heat-shock } \\
\text { promoter element to activate } \\
\text { heat-shock response genes } \\
\text { under conditions of heat or } \\
\text { other stresses [81]. }\end{array}$ \\
\hline
\end{tabular}

SYCP2 (synaptonemal complex protein 2)

A-MYB/MYBL 1 (myeloblastosis

oncogene-like 1)

20q13.33 The gene codes for a major component of the synaptonemal complex, which is required for normal meiotic chromosome synapsis during oocyte and spermatocyte development and for normal male and female fertility [84]

MYBL 1 protein is a male-specific master regulator of meiotic genes that are involved in mul tiple processes in spermatocytes, particularly processes involved in cell cycle progression through pachynema [87].

TEX11 (testis expressed 11)

Xq13.1 TEX11 protein is required for spermatogenesis; particularly certain levels of the protein are required for meiotic progression. The protein is also necessary for normal genomewide meiotic recombination rates in both sexes [88].

KIT (v-kit Hardy-Zuckerman 4 feline sarcoma viral oncogene homolog)

ADGRG2 (adhesion G proteincoupled receptor G2)
$4 q 12$

The gene is embedded in the reproductive cells and encoded receptor tyrosine kinases, which is involved in signal transduction. The protein takes part in phosphorylation that activates a series of proteins in multiple signaling pathways, which are necessary for normal cell growth, proliferation, survival, and movement in the reproductive cells and certain other cell types [90].

Xp22.13 This gene encodes an epididymis-specific transmembrane protein, which is involved in a signal transduction pathway controlling epididymal function and male fertility. May particularly regulate fluid exchange within the epididymis [92].

7q11.23 Encodes a protein that functions in immunoregulation homologous chromosome pairing in meiosis during spermatogenesis and cellular

causes recurrent pregnancy loss [79].

Heterozygous missense mutations have been reported [82].

Heterozygous frameshift mutation and deletion have been reported in the gene [85].
HSF2-null male mice showed embryonic lethality, neuronal defects, and reduced spermatogenesis that relates to meiotic arrest, increased sperm apoptosis, and seminiferous tubule dysgenesis [83]. Male humans showed azoospermia [82].

Alters synaptonemal complex, disrupting spermatogenesis and resulting in cryptozoospermia and azoospermia $[85,86]$.

A variant named repro9 involving a $\mathrm{C}$ to $\mathrm{A}$ transversion at nucleotide 893 of the MYBL mRNA was reported [87]. MYBL 1-/-, showing meiotic arrest similar to repro9, has also been reported [87].

Frameshift mutations were observed, so also missense mutations, particularly a missense mutation tagged V748A was observed among transgenic mice [88].

A SNP in which Asp-816 is rea at exon 17 has been reported [91].

Three protein-truncating hemizygous mutations, named c.1545dupT (p.Glu516Ter), c.2845delT (p.Cys949AlafsTer81), and c.2002 2006delinsAGA (p.Leu668ArgfsTer21), have been reported [93].

Deletion in the exon 8 of the gene has been reported [95].

Causes spermatogenic failure resulting in azoospermia or severe oligozoospermia [96].
Causes meiotic arrest in spermatocytes, characterized by defects in autosome synapsis in pachynema, unsynapsed sex chromosomes, incomplete double-strand break repair on synapsed pachytene chromosomes and a lack of crossing over [87]. mice, resulting in spermatogenic failure, X-linked, 2 (SPGFX2), a disorder characterized by mixed testicular atrophy and azoospermia [89]. Among humans, meiotic arrest leads to non-obstructive azoospermia [88].

\section{Causes seminomas and}

Predisposes to congenital bilateral aplasia of the vas deferens, X-linked (CBAVDX), a disease characterized by bilateral absence of vas deferens and obstructive azoospermia [92].
Causes meiotic arrest in male 
Table 2 Genes predisposing to nonsyndromic spermatogenic failure and sperm morphological abnormalities (Continued)

\begin{tabular}{|c|c|c|}
\hline & & $\begin{array}{l}\text { processes involving protein } \\
\text { folding and trafficking [94]. }\end{array}$ \\
\hline PRM1 (protamine 1) & $16 p 13.13$ & $\begin{array}{l}\text { It encodes a protein called } \\
\text { protamine 1, which replaces } \\
\text { histone during developmental } \\
\text { stages of elongating spermatids } \\
\text { and compact sperm DNA into a } \\
\text { highly condensed, stable, and } \\
\text { inactive complex to ensure that } \\
\text { quality spermatozoa are } \\
\text { produced and as well protect } \\
\text { spermatozoa from the } \\
\text { degrading effects of free } \\
\text { radicals [97]. }\end{array}$ \\
\hline PRM2 (protamine 2) & $16 p 13.13$ & $\begin{array}{l}\text { PRM2 secretes protamine } 2 \text {, } \\
\text { which replaces histone during } \\
\text { spermatid development, } \\
\text { condensing chromatin, and } \\
\text { compacting the DNA to ensure } \\
\text { production of quality } \\
\text { spermatozoa and prevent } \\
\text { degradation by free radicals } \\
\text { [97]. }\end{array}$ \\
\hline TNP1 (nuclear transition protein 1) & $2 q 35$ & $\begin{array}{l}\text { The gene encodes nuclear } \\
\text { proteins, which replace nuclear } \\
\text { histones and in turn substituted } \\
\text { by protamine } 1 \text { and } 2 \text { during } \\
\text { spermatogenesis [101]. }\end{array}$ \\
\hline
\end{tabular}

TNP2 (nuclear transition protein 2)

DAZ1 (deleted in azoospermia 1)

XRCC2 (X-ray repair cross complementing 2)

cCDC62 (coiled-coil domain containing 62)

EFCAB9 (EF-hand calcium21 binding domain-containing protein 9)

16p13.13 TNP2 participates in the removal of the nucleohistones and in the initial condensation of the spermatid nucleus, thus contributes to the dense packing of spermatid chromatin during spermatogenesis [103]. protein 1, which is necessary for spermatogenesis. It binds to the 3'-UTR of mRNAs, regulating their translation, and promoting germ cell progression to meiosis and the formation of haploid germ cells [104].

7q36.1 XRCC2 protein was shown in mice to be required for genetic stability, embryonic neurogenesis and viability [107].

12q24.31 Encodes a nuclear receptor coactivator that enhances estrogen receptor transactivation [109]. The gene is expressed in the acrosome of developing spermatids and mature sperms, showing that it is necessary for spermatogenesis [110].

$5 q 35.1$
A SNP named g.IVS1+75T>C was reported by Heidan et al [102]. A deletion of 15 nucleotides in the 5'-promoter region of the gene was also reported [101].

A variant named G1272C was reported [98].

A SNP, known as $-190 \mathrm{C}>\mathrm{A}$ (rs2301365), was identified in both PRM1 and 2 [99].

\section{Causes chromatin damage and DNA breaks, resulting in sperm structural defects, reduced motility, and defective spermatogenesis due to haploinsufficiency [100].}

Disrupts the highly condensed structure of the sperm nuclear chromatin, resulting in abnormal spermatogenesis [102]. Also causes varicocele, due to the failure of ipsilateral testicular growth and development [102].

TNP2-/- in mice affects sperm chromatin structure, causing sperm head abnormalities, acrosome abnormalities in which the acrosomes do not attach to the nuclear envelope, and reduced sperm motility, resulting in tetrazoospermia [103]. Encodes sperm-specific EF-band EFCAB9 deletions were domain protein, which is essen- reported [111]. tial for activation of CATSPER channel that regulates sperm motility [111].
$D A Z 1$ deletions were reported [105].

Causes Y chromosome infertility known as spermatogenic failure Y-linked 2 (SPGFY2), a disorder resulting in azoospermia or oligozoospermia [104]. Also causes sperm structural abnormalities and reduced motility [106].

A SNP in the gene involving c.41T>C substitution was reported [108].

A nonsense mutation in the exon 6, which results in the formation of a premature stop was reported by Li et al. [110].

Causes meiotic arrest, resulting in azoospermia [108].

Causes defective sperm morphology and reduced motility [110].

Disrupts CATSPER channel signaling, which affects sperm motility [111]. codon and a truncated protein, 
Table 2 Genes predisposing to nonsyndromic spermatogenic failure and sperm morphological abnormalities (Continued)

\begin{tabular}{|c|c|c|c|c|}
\hline KLHL10 (Kelch-like family member 10) & $17 q 21$ & $\begin{array}{l}\text { KLHL10 encodes a germ cell- } \\
\text { specific protein essential for } \\
\text { spermatogenesis [63]. }\end{array}$ & $\begin{array}{l}\text { Two missense mutations } \\
\text { named } A 313 T \text { and } Q 216 P \text { were } \\
\text { reported [112]. }\end{array}$ & $\begin{array}{l}\text { Impairs homodimerization, } \\
\text { resulting in germ cell loss, } \\
\text { abnormal spermatids, and } \\
\text { severe oligozoospermia [112]. }\end{array}$ \\
\hline SEPT12 (septin 12) & $16 p 13.3$ & $\begin{array}{l}\text { The gene codes for septin } 12, \\
\text { which is expressed exclusively } \\
\text { in the testis and involved in } \\
\text { spermatogenesis, especially } \\
\text { morphogenesis of sperm heads } \\
\text { and the elongation of sperm } \\
\text { tails [63]. }\end{array}$ & $\begin{array}{l}\text { Two missense mutations } \\
\text { named c.266C }>\text { T/p.Thr8 Met } \\
\text { and c.589G }>\text { A/p.Asp } 197 \text { Asn } \\
\text { were reported by Kuo et al. } \\
\text { [113]. }\end{array}$ & $\begin{array}{l}\text { Disrupts the structural integrity } \\
\text { of sperm by perturbing septin } \\
\text { filament formation, causing } \\
\text { various sperm abnormalities, } \\
\text { including immotility, bent tails, } \\
\text { acrosome breakage, round } \\
\text { heads, and significant } \\
\text { spermatozoa DNA damage, as } \\
\text { well as oligoasthenozoosperm } \\
\text { and asthenoteratozoospermia } \\
{[63,113] \text {. }}\end{array}$ \\
\hline $\begin{array}{l}\text { TAF4B (TATA-box binding protein } \\
\text { associated factor } 4 b \text { ) }\end{array}$ & $18 q 11.2$ & $\begin{array}{l}\text { TAF4B encodes a transcriptional } \\
\text { coactivator and involved in } \\
\text { folliculogenesis, } \\
\text { spermatogenesis, and } \\
\text { oogenesis [114]. }\end{array}$ & $\begin{array}{l}\text { A nonsense mutation in exon } 9 \\
\text { named p.R611X was reported } \\
{[115] .}\end{array}$ & $\begin{array}{l}\text { Causes spermatogenic failure } \\
13 \text { (SPGF13), a disorder resulting } \\
\text { in azoospermia or } \\
\text { oligozoospermia [114]. }\end{array}$ \\
\hline $\begin{array}{l}\text { ZMYND15 (zinc finger mynd- } \\
\text { containing protein 15) }\end{array}$ & $17 p 22.1$ & $\begin{array}{l}\text { ZMYND15 codes for a } \\
\text { transcription repressor, which in } \\
\text { mice is expressed exclusively in } \\
\text { the haploid germ cells, } \\
\text { particularly during late } \\
\text { spermatogenesis [116]. }\end{array}$ & $\begin{array}{l}\text { A mutation in exon } 9 \text { of the } \\
\text { gene named p.K507Sfs*3 was } \\
\text { reported by Ayhan et al. [115]. }\end{array}$ & $\begin{array}{l}\text { Causes spermatogenic failure } \\
14 \text { (SPGF14), a disorder resulting } \\
\text { in azoospermia or } \\
\text { oligozoospermia [117]. }\end{array}$ \\
\hline $\begin{array}{l}\text { NANOS1 (nanos C2HC-type zinc fin- } \\
\text { ger 1) }\end{array}$ & 10q26.11 & $\begin{array}{l}\text { This gene encodes a CCHC-type } \\
\text { zinc finger protein that is specif- } \\
\text { ically expressed in the germ } \\
\text { cells of adult men and regulates } \\
\text { the translation by acting as a } \\
\text { post-transcriptional repressor } \\
\text { [118]. }\end{array}$ & $\begin{array}{l}\text { Two deletion mutations called } \\
\text { p.Pro77_Ser78delinsPro and } \\
\text { p.Ala173del have been reported } \\
\text { [119]. }\end{array}$ & $\begin{array}{l}\text { Results in spermatogenic failure } \\
12 \text { (SPGF12), an infertility } \\
\text { disorder caused by } \\
\text { spermatogenesis defects, } \\
\text { characterized by decreased } \\
\text { sperm motility and } \\
\text { concentration, sperm structural } \\
\text { defects, non-obstructive azoo- } \\
\text { spermia, oligozoospermia, and } \\
\text { oligo-astheno-teratozoospermia } \\
\text { [120]. }\end{array}$ \\
\hline $\begin{array}{l}\text { GALNTL5 (polypeptide N- } \\
\text { acetylgalactosaminyltransferase Like } \\
\text { 5) }\end{array}$ & $7 q 36.1$ & $\begin{array}{l}\text { GALNTL5 encodes an inactive } \\
\text { protein, which is expressed in } \\
\text { the testis and is required during } \\
\text { spermatid development in } \\
\text { which it participates in protein } \\
\text { loading into the acrosomes } \\
\text { [121]. }\end{array}$ & $\begin{array}{l}\text { Heterozygous single nucleotide } \\
\text { deletion of maternal } \\
\text { inheritance was reported [63, } \\
\text { 122]. }\end{array}$ & $\begin{array}{l}\text { Decreases glycolytic enzymes, } \\
\text { which disrupts protein loading } \\
\text { into acrosomes, resulting in } \\
\text { asthenozoospermia and poor } \\
\text { sperm motility [122]. }\end{array}$ \\
\hline
\end{tabular}

oocytes undergoing meiotic maturation. Mutations in the genes may also cause ovarian dysgenesis, characterized by absence or puberty delay, primary amenorrhea, uterine hypoplasia, and hypogonadotropic hypogonadism. Some mutations prevent the formation of primordial follicles, resulting in reduced oocyte numbers after birth.

In summary, 23 genes, representing 35\%, were linked with syndromic infertility, while 42 genes, accounting for $65 \%$ cause nonsyndromic infertility. Of the 42 nonsyndromic genes, 26 predispose to spermatogenic failure and sperm morphology abnormalities, 11 cause ovarian failures, and 5 cause sex reversal and puberty delay. Overall, 31 genes (48\%) predispose to male infertility, 15 genes $(23 \%)$ cause female infertility, and 19 genes (29\%) predispose to both. The common features of male infertility were spermatogenic failure and sperm morphology abnormalities, while ovarian failure has been the most frequently reported among infertile females. This analysis infers that male genetic infertility was more prevalent than female, with spermatogenic failure and sperm morphology abnormalities being most prevalent.

\section{Genetic testing for infertility disorders}

Knowing the exact cause of infertility allows for better diagnostic decisions and enables enhanced counseling for parents with regard to risks to their children. For this reason, when there is a means, testing of embryos should be recommended for a family with a history of genetic infertility disorders discussed above. Moreover, every healthy-looking individual is a carrier of between 5 to 8 recessive genetic disorders; so the test should be 
Table 3 Genes predisposing to nonsyndromic sex reversal and pubertal delay

\begin{tabular}{|c|c|c|c|c|}
\hline $\begin{array}{l}\text { GNRHR } \\
\text { (gonadotropin- } \\
\text { releasing } \\
\text { hormone } \\
\text { receptor) }\end{array}$ & $4 q 13.2$ & $\begin{array}{l}\text { This gene encodes the receptor for type } \\
1 \text { gonadotropin-releasing hormone, a re- } \\
\text { ceptor that is expressed on the surface of } \\
\text { pituitary gonadotrope cells, lymphocytes, } \\
\text { breast, ovary, and prostate. GNRHR be- } \\
\text { comes activated after binding with } \\
\text { gonadotropin-releasing hormone, and }\end{array}$ & $\begin{array}{l}\text { At least } 19 \text { different mutations have } \\
\text { been identified, including } \\
\text { heterozygous mutations named } \\
\text { Gln106Arg/Arg262Gln and Arg262G/n/ } \\
\text { Tyr28Cys [17] as well as homozygous } \\
\text { missense mutation named g. G7167A; } \\
\text { p. Arg139His [124]. }\end{array}$ & $\begin{array}{l}\text { Causes low levels of circulating } \\
\text { gonadotropins and testosterone, } \\
\text { resulting in hypogonadotropic } \\
\text { hypogonadism } 7 \text { (HH7), a disorder } \\
\text { characterized by absent or incomplete } \\
\text { sexual maturation by the age of } 18 \\
\text { years [125]. }\end{array}$ \\
\hline
\end{tabular}
the complex formed causes the release of gonadotropic luteinizing hormones (LH) and follicle-stimulating hormones (FSH) [123].

PROP1 (PROP $5 \mathrm{q} 35.3$ The gene produces a transcription factor paired-like homeobox 1)

embedded only in the pituitary gland and releases hormones for growth, reproduction, and cell differentiation in the pituitary gland [126].

\section{DMRT1 \\ (doublesex- and \\ MAB3-related transcription fac- tor 1)}

SOX3 (SRY-box transcription factor 3) 9p24.3 The gene encodes a transcription factor expressed in the testis and involved in male sex determination and differentiation before and after birth by promoting male-specific genes and repressing female-specific genes. May also play a minor role in oogenesis [127].

Xq27.1 The gene codes for a transcription factor embedded in the hypothalamus and pituitary gland where it regulates neuronal development and differentiation, and as well promote male sex development [128].

RSPO1 (Rspondin 1)

\author{
1 p34.3 Produces a protein that is essential in \\ ovary determination through regulation \\ of Wnt signaling [129].
}

Deletions in the gene had been reported [127]. reported, the most common of which deletes two amino acids, written as 301-302delAG [126]. two duplications of about $123 \mathrm{~kb}$ and $85 \mathrm{~kb}$, a $343 \mathrm{~kb}$ deletion immediately upstream of $\mathrm{SO} 3$, and a large

duplication of approximately $6 \mathrm{Mb}$ that encompasses SOX3 have been reported [128].

c. $286+1 G>A$ [130].
Reduces pituitary cell differentiation and prevents the release of hormones from the pituitary gland, causing a condition called combined pituitary hormone deficiency, with features like short stature and delayed or absent puberty [126].

Predisposes to male-to-female sex reversal in the presence of a normal 46 , $X Y$ karyotype, referred to as $46, X Y$ sex reversal 4 (SRXY4), characterized by complete or partial gonadal dysgenesis. The mutation may also cause testicular germ cell tumors [127].

Causes $46, X X$ sex reversal 3 (SRXX3), characterized by XX male reversal and a complex phenotype that includes scrotal hypoplasia, microcephaly, developmental delay, and growth retardation [128]. Also causes 46, XX testicular disorder of sex development [128].

Causes oocytes depletion and masculinized ovaries, resulting in XX true hermaphroditism, also known as an ovotesticular disorder of sexual development, a disorder of gonadal development characterized by the presence of both ovarian and testicular tissue in $46, \mathrm{XX}$ individuals [130]. extended to everyone who has the means [157]. It is specifically recommended for embryos of couples who are recessive for a gene infertility disorder.

The conventional method used in genetic testing of embryos is the whole sequence amplification. After fertilization, the embryo undergoes mitotic divisions for 5 to 7 days, ending with the development of the blastocyst stage. A biopsy of some blastocysts is done, after which a whole genome amplification of the cells is conducted, usually using polymerase chain reaction [157, 158]. This technique is laborious, time-consuming, and expensive, so recently, a new technique known as the next-generation sequencing is being used for testing genetic disorders in infertile couples and embryos [159]. The protocol is based on an enlarged panel of diseaseassociated genes (approximately 5000 genes). The large panel of marker genes allows the identifications of a large number of target and non-target genes [157]. However, the technique has some limitations too, which is its inability to detect haploidies, polyploidies, and mosaicisms [157].

\section{Conclusion}

Several studies reviewed showed that certain genes embedded in the hypothalamus, pituitary gland, gonads, and gonadal outflow regulate fertility in both males and females. However, mutational inactivation of these genes may cause syndromic or nonsyndromic infertility. The common features of male infertility include spermatogenic failure, resulting in azoospermia, oligospermia, and chromosome structural abnormalities. Most females express ovarian failure, resulting in menstrual dysfunction 
Table 4 Genes predisposing to nonsyndromic ovarian failure

\begin{tabular}{|c|c|c|c|}
\hline $\begin{array}{l}\text { BMP15 (bone } \\
\text { morphogenetic } \\
\text { protein 15)/GDF9B } \\
\text { (growth/ } \\
\text { differentiation factor } \\
\text { 9B) }\end{array}$ & Xp11.22 & $\begin{array}{l}\text { The gene encodes a member of } \\
\text { transforming growth factor-beta } \\
\text { superfamily, which plays a role in oo- } \\
\text { cyte maturation and follicular develop- } \\
\text { ment, through activation of granulosa } \\
\text { cells [131]. }\end{array}$ & $\begin{array}{l}\text { Several missense mutations reported } \\
\text { [131]. }\end{array}$ \\
\hline
\end{tabular}

FIGLA (factor in germline alpha)

NOBOX (newborn ovary homeobox)

SALL4 (SAL-like 4)

FSHB (folliclestimulating hormone subunit beta) 2p13.3 FIGLA encodes a germ cell-specific basic helix-loop-helix transcription factor that regulates the expression of the zona pellucida- and oocytespecific genes, particularly genes involved in folliculogenesis [30, 133].
Missense mutations and deletions that resulted in a frameshift had been reported [134].

Missense mutations in the homeobox domain were observed in infertile Caucasian or African descent [138]. regulator with a homeobox motif and is important for early folliculogenesis [137].

20q13.2 The gene is expressed in the testis and oocytes and secretes putative zinc finger transcription factor that plays a role in the pluripotency of oocytes and maintenance of undifferentiated spermatogonia [38, 140].

11p14.1 This gene encodes the beta subunit of Tyr76X, Cys51Gly, and Val61X were the follicle-stimulating hormone which reported [38]. in association with luteinizing hormone induces egg and sperm production $[38,142]$

HCG $\beta$ (human chorionic gonadotrophin)

SOHLH1 (spermatogenesis and oogenesisspecific basic helixloop-helix 1) 19q13.3 HCG 3 encodes a hormone called HCG which is secreted mainly by the placenta and is important for normal progression of pregnancy by maintaining the production of steroid hormones and other growth factors in the corpus luteum [144].

9q34.3 This gene encodes one of the testisspecific transcription factors which are essential for spermatogenesis, oogenesis, and folliculogenesis. The protein is necessary for spermatogonial proliferation and differentiation as well as regulates both male and female germline differentiation [147].
Deletions [140]. CGB5 p.Val56Leu (rs72556325) and CGB8 p.Pro73Arg

Alternatively spliced transcript variants encoding different isoforms have been found for this gene [147].
Causes ovarian dysgenesis 2

(ODG2), a disorder characterized by lack of spontaneous pubertal development, primary amenorrhea, uterine hypoplasia, and hypergonadotropic hypogonadism as a result of streak gonads [132]. May also cause premature ovarian failure 4 (POF4), a disorder in which the ovarian function stops before the age of 40 years and is characterized by oligomenorrhea or amenorrhea, in the presence of elevated levels of serum gonadotropins and low estradiol $[131,132]$.

FIGLA knockout in female mice prevents formation of primordia follicles, and oocyte numbers drop rapidly after birth [135]. May also cause haploinsufficiency, predisposing to premature ovarian failure 6 (POF6), an ovarian disorder defined as the cessation of ovarian function under the age of 40 years and is characterized by oligomenorrhea or amenorrhea, in the presence of elevated levels of serum gonadotropins and low estradiol [134, 136].

Predisposes to POF [139].

Predisposes to nonsyndromic POF $[140,141]$.

Causes low FSH and estradiol, and high LH among females, resulting in the absence or incomplete breast development and sterility [143]. Males produce low androgen, leading to low testosterone and azoospermia, but puberty may be normal or absent [38].

Causes low levels of HCG during the first trimester of pregnancy, (rs72556345) had been reported [145]. resulting in miscarriage and ectopic pregnancy [146].

Causes ovarian dysgenesis 5 (ODG5), a disorder characterized by lack of spontaneous pubertal development, primary amenorrhea, uterine hypoplasia, and hypergonadotropic hypogonadism [147]. May also result in spermatogenic failure 32 (SPGF32), a condition that is characterized by non-obstructive azoospermia [148]. 
Table 4 Genes predisposing to nonsyndromic ovarian failure (Continued)

\begin{tabular}{|c|c|c|}
\hline $\begin{array}{l}\text { SOHLH2 } \\
\text { (spermatogenesis } \\
\text { and oogenesis } \\
\text { specific basic helix- } \\
\text { loop-helix 2) }\end{array}$ & $13 q 13.3$ & $\begin{array}{l}\text { The } S O H L H 2 \text { is expressed specifically in } \\
\text { spermatogonia and oocytes and is } \\
\text { required for early spermatogonial and } \\
\text { oocyte differentiation [149]. SOHLH2 is } \\
\text { a transcription regulator of both male } \\
\text { and female germline differentiation } \\
\text { and together with } S O H L H 1 \text { regulates } \\
\text { oocyte growth and differentiation } \\
\text { [150]. }\end{array}$ \\
\hline
\end{tabular}

PGRMC1

(progesterone

receptor membrane component 1)

Xq24 The gene codes for progestin receptor membrane component 1, which associates with and transports a wide range of molecules, including steroids, and the gene has been demonstrated in zebrafish to function in oocyte maturation and meiosis resumption [154].

\begin{abstract}
ESR1 (estrogen receptor 1)
\end{abstract}

HES1 (Hes family bHLH transcription factor 1) 6q25.1- Estrogen receptor alpha regulates q25.2 estrogen action in all reproductive tissues. Estrogen signaling mediates leukemia inhibitory factor expression, which is a cytokine critical for blastocyst implantation [155].

3q29 Hes is expressed in the ovary and encodes transcriptional factors necessary for oocyte survival and maturation [156].
At least 11 mutant variants of SOHLH2 SOHLH2 knockout causes defects in gene have been reported [151]. In particular, two variants, named rs6563386 and rs 1328626, were reported by Song et al. [152].

Mutant alleles named ecu4, $f 21$, and sa37360 were reported in zebrafish (ZFIN) [154].

A SNP named rs9340799 was reported Causes estrogen resistance, [155]. resulting in absence of pubertal growth and endometriosis-related infertility [155].

Deletions were reported [156].

HES1 knockout reduces notch signaling and elevates apoptosis, decreasing the number, size, and maturation of oocytes [156]. and pregnancy loss. Males and females may also express sex reversal, pubertal delay or absence, and genital abnormalities such as micro-penis and absence of the breast. Male genetic infertility was more prevalent than female, with spermatogenic failure and sperm morphology abnormalities being most prevalent. The mechanisms leading to these pathologies are gene-specific, which, if targeted in the affected, may lead to improved treatment. Medical practitioners are advised to target these genes in the affected.

\section{Abbreviations}

AIS: Androgen insufficiency syndrome; BBS: Bordet-Biedl syndrome; CBAVD: Congenital bilateral absence of the vas deferens; CF: Cystic fibrosis; FSH: Follicle-stimulating hormone; FXPOI: Fragile X-associated primary ovarian insufficiency; GHR: Genetic home reference; HH: Hypogonadotropic hypogonadism; LH: Luteinizing hormone; NCBI: National Center for Biotechnology Information; OHSS: Ovarian hyperstimulation syndrome; ODG: Ovarian dysgenesis; PCOS: Polycystic ovary syndrome; POF: Premature ovarian failure; SCOS: Sertoli cell-only; SNP: Single nucleotide polymorphism; SPGF: Spermatogenic failure

\section{Acknowledgments}

Not applicable.

\section{Authors' contributions}

TOY conceptualized and did literature searches, article writing, and correspondence. UUL, HA, YSK, SSR, ZA, and SA did literature searches, sorting, and referencing. All authors proofread and approved the final manuscript.

\section{Availability of data and materials}

Not applicable.

Ethics approval and consent to participate

Not applicable.

\section{Consent for publication}

Not applicable.

\section{Competing interests}

The authors declare that they have no competing interests.

\section{Author details}

${ }^{1}$ Department of Biolog, Federal University Birnin-Kebbi, PMB 1157, Birnin-Kebbi, Nigeria. ${ }^{2}$ Department of Biochemistry and Molecular Biology, Federal University Birnin-Kebbi, Birnin-Kebbi, Nigeria.

Received: 12 June 2020 Accepted: 7 August 2020

Published online: 09 November 2020

\section{References}

1. Venkatesh T, Suresh PS, Tsutsumi R (2014) New insights into the genetic basis of infertility. Appl Clin Genet. 7:235-243. https://doi.org/10.2147/TACG. S40809

2. Agarwal $A$, Mulgund $A, H a m a d a, A$, et al. A unique view on male infertility around the globe. Reprod Biol Endocrinol. 2015; 13: 37 https://doi.org/10. 1186/s12958-015-0032-1.

3. Chowdhury SH, Cozma Al, Chowdhury JH. Infertility. Essentials for the Canadian Medical Licensing Exam: review and prep for MCCQE Part I. 2nd edition. Wolters Kluwer. Hong Kong. 2017.

4. Mascarenhas MN, Flaxman SR, Boerma T et al (2012) National, regional, and global trends in infertility prevalence since 1990: a systematic analysis of 277 health surveys. PLoS Med. 9:e1001356 https://dx.plos.org/10.1371

5. Odunvbun W, Oziga D, Oyeye L, Ojeogwu C (2018) Pattern of infertility among infertile couple in a secondary health facility in Delta State, South South Nigeria. Trop J Obstet Gynaecol. 35:244-248. https://doi.org/10.4103/ TJOG.TJOG_61_18

\section{Funding}

Not applicable. 
6. Kumar N, Singh AK (2015) Trends of male factor infertility, an important cause of infertility: a review of literature. J Hum Reprod Sci. 8:191-196. https://doi.org/10.4103/0974-1208.170370

7. The ESHRE Capri Workshop Group (2002) Physiopathological determinants of human infertility. Hum Reprod Update. 8(5):435-447

8. Brugo-Olmedo S, Chillik C, Kopelman S (2001) Definition and causes of infertility. Reprod BioMed Online. 2(1):41-53. https://doi.org/10.1016/s14726483(10)62187-6

9. Durairajanayagam D (2018) Lifestyle causes of male infertility. Arab J Urol. 16(1):10-20. https://doi.org/10.1016/j.aju.2017;12:004

10. Ferlin A, Raicu F, Gatta V et al (2007) Male infertility: role of genetic background. Reprod Biomed Online. 14:734-745. https://doi.org/10.1016/ s1472-6483(10)60677-3

11. O'Flynn O'Brien KL, Varghese AC, Agarwal A (2010) The genetic causes of male factor infertility: a review. Fertil. Steril. 93:1-12. https://doi.org/10.1016/ j.fertnstert.2009.10.045

12. Genetic Home Reference. 2020. CFTR gene. Available at https://ghr.nIm.nih. gov/gene/CFTR.

13. Tahmasbpour E, Balasubramanian D, Agarwal A (2014) A multi-faceted approach to understanding male infertility: gene mutations, molecular defects and assisted reproductive techniques (ART) J. Assist Reprod Genet. 31:1115-1137. https://doi.org/10.1007/s10815-014-0280-6

14. Dada R, Thilagavathi J, Venkatesh S, Esteves SC, Agarwal A (2011) Genetic testing in male infertility. Open Reprod Sci. 3:42-56. https://doi.org/10.2174/ 1874255601103010042

15. Ajonuma LC, Ng EH, Chow PH et al (2005) Increased cystic fibrosis transmembrane conductance regulator (CFTR) expression in the human hydrosalpinx. Hum Reprod. 20(5):1228-1234. https://doi.org/10.1093/ humrep/deh773

16. Genetic Home Reference. 2020. NR5A1 gene. Available at .

17. Jedidi I, Ouchari M, Yin Q (2018) Autosomal single-gene disorders involved in human infertility. Saudi J Biol Sci. 25(5):881-887. https://doi.org/10.1016/j. sjbs.2017.12.005

18. Bashamboo A, Ferraz-de-Souza B, Lourenço D et al (2010) Human male infertility associated with mutations in NR5A1 encoding steroidogenic factor 1. Am J Hum Genet. 87:505-512. https://doi.org/10.1016/j.ajhg.2010.09.009

19. Fabbri HC, de Andrade JGR, Soardi FC, et al. The novel p.Cys65Tyr mutation in NR5A1 gene in three 46, XY siblings with normal testosterone levels and their mother with primary ovarian insufficiency. BMC Med Genet. 2014; 15:7. DOI: 10.1186/1471-2350-15-7.

20. Genetic Home Reference. 2020. WT1 gene. Available at https://ghr.nlm.nih. gov/gene/WT1.

21. Nathan A, Reinhardt P, Kruspe D et al (2017) The Wilms tumor protein Wt1 contributes to female fertility by regulating oviductal proteostasis. Hum Mol Genet. 26:1694-1705. https://doi.org/10.1093/hmg/ddx075

22. Wang XN, Li ZS, Ren Y et al (2013) The Wilms tumor gene, Wt1, is critical for mouse spermatogenesis via regulation of Sertoli cell polarity and is associated with non-obstructive azoospermia in humans. PLoS Genet. 9: e1003645. https://doi.org/10.1371/journal.pgen.1003645

23. Sakamoto J, Takata A, Fukuzawa R et al (2001) A novel WT1 gene mutation associated with Wilms' Tumor and congenital male genitourinary malformation. Pediatr Res. 50:337-344. https://doi.org/10.1203/00006450200109000-00008

24. Seabra CM, Quental S, Lima AC et al (2015) The mutational spectrum of WT1 in male infertility. J Urol. 193:1709-1715. https://doi.org/10.1016/j.juro. 2014.11.004

25. Wang $Y$, Xiao M, Chem $X$ et al (2015) WT1 recruits TET2 to regulate its target gene expression and suppress leukemia cell proliferation. Is. Mol Cell. 57(4):662-673. https://doi.org/10.1016/j.molcel.2014.12.023

26. Genetic Home Reference. 2020. FMR1 gene. Available at https://ghr.nlm.nih. gov/gene/FMR1. .

27. Coffee B, Keith K, Albizua I et al (2009) Incidence of fragile X syndrome by newborn screening for methylated FMR1 DNA. Am J Hum Genet. 85(4):503514. https://doi.org/10.1016/j.ajhg.2009.09.007

28. Genetic Home Reference. 2020. GALT gene. Available at https://ghr.nlm.nih. gov/gene/GALT\#conditions.

29. Fridovich-Keil JL, Gubbels CS, Spencer JB (2011) Ovarian function in girls and women with GALT-deficiency galactosemia. J Inherit Metab Dis. 34(2): 357-366. https://doi.org/10.1007/s10545-010-9221-4

30. Zorrilla M, Yatsenko AN (2013) The genetics of infertility: current status of the field. CurrGenet Med Rep. 1(4):10. https:/doi.org/10.1007/s40142-013-0027-1
31. National Center for Biotechnology Information. 2020. GDF9 growth differentiation factor 9 [Homo sapiens (human)]. Available at https://www. ncbi.n/m.nih.gov/gene/2661.

32. Zhao H, Qin Y, Kovanci E, Simpson JL, Chen ZJ, Rajkovic A (2007) Analyses of GDF9 mutation in 100 Chinese women with premature ovarian failure. Fertil Steril. 88(5):1474-1476. https://doi.org/10.1016/j.fertnstert.2007.01.021

33. Uniport .2020. UniProtKB - 060383 (GDF9_HUMAN). Available at https:// www.uniprot.org/uniprot/O60383. Accessed March 18, 2020.

34. Genetic Home Reference. 2020.. MED12 gene. Available at https://ghr.nlm. nih.gov/gene/MED12\#conditions. .

35. Genetic Home Reference. 2020. ANOS1 gene. Available at https:/ghr.nlm. nih.gov/gene/ANOS1\#location.

36. Lopategui DM, Griswold AJ, Arora H, Clavijo Rl, Tekin M, Ramasamy R (2018) A rare ANOS1 variant in siblings with Kallmann syndrome identified by whole exome sequencing. Androl. 6(1):53-57. https://doi.org/10.1111/ andr.12432

37. Genetic Home Reference. 2020. LEP gene. Available at https://ghr.nIm.nih. gov/gene/LEP\#location.

38. Layman LC (2002) Human gene mutations causing infertility. J Med Genet 39:153-161. https://doi.org/10.1136/jmg.39.3.153

39. Hodžić AM, Ristanović B, Zorn C et al (2017) Genetic variation in leptin and leptin receptor genes as a risk factor for idiopathic male infertility. Androl. 5(1):70-74. https://doi.org/10.1111/andr.12295

40. Genetic Home Reference. 2020. LEPR gene. Available at https://ghr.nlm.nih. gov/gene/LEPR\#location. .

41. Genetic Home Reference. 2020. NROB1 gene. Available at https://ghr.nlm. nih.gov/gene/NR0B1\#location. .

42. Genetic Home Reference. 2020. HESX1 gene. Available at https://ghr.nlm. nih.gov/gene/HESX1\#location.

43. National Center for Biotechnology Information. 2020. LHB gene. Available at https://ghr.nlm.nih.gov/gene/LHB\#location.

44. El-Shal SA, Zidan HE, Rashad MN, Abdelaziz AM, Harira MM (2016) Association between genes encoding components of the leutinizing hormone/luteinizing hormone choriogonadotrophin receptor pathway and polycystic ovary syndrome in Egyptian women. Inter Union of Biochem Mol Biol. 68(1):23-36. https://doi.org/10.1002/iub.1457

45. Reen JK, Kerekoppa R, Deginal R et al (2018) Luteinizing hormone beta gene polymorphism and its effect on semen quality traits and luteinizing hormone concentrations in Murrah buffalo bulls. Asian-Australas J Anim Sci. 31(8):1119-1126. https://doi.org/10.5713/ajas.17.0679

46. Genetic Home Reference. 2020. LHCGR gene. Available at https://ghr.nIm. nih.gov/gene/LHCGR.

47. Genetic Home Reference. 2020. AR gene. Available at https://ghr.nlm.nih. gov/gene/AR\#location.

48. Genetic Home Reference. 2020. SRY gene. Available at https:/ghr.nlm.nih. gov/gene/SRY\#synonyms.

49. Lerchbaum B, Obermayer-Pietsch B (2012) Vitamin D and fertility: a systematic review. Eur JEndocrinol. 166:765-778. https://doi.org/10.1530/EJE-11-0984

50. Genetic Home Reference. 2020. VDR gene. Available at https://ghr.nlm.nih gov/gene/NDR\#location.

51. Reginatto MW, Pizarro BM, Antunes RA, Mancebo ACA, Hoffmann L, Fernandes P. Vitamin D receptor Taql polymorphism is associated with reduced follicle number in women utilizing assisted reproductive technologies. Front Endocrinol. 2018; 9: 252.| https://doi.org/10.3389/fendo.2018.00252.

52. Bagheri M, Abdi Rl, Hosseini JN, Nanbakhsh F (2013) Vitamin D receptor Taql gene variant in exon 9 and polycystic ovary syndrome risk. Int J Fertil Steril. 7(2):116-121

53. Szczepańsk M, Mostowska A, Wirstlein P, Skrzypczak J. Matthew MM, Jagodziński PP. Polymorphic variants in vitamin D signaling pathway genes and the risk of endometriosis-associated infertility. Mol Med Rep. 2015; 12 (5): 7109-7115. https://doi.org/10.3892/mmr.2015.4309.

54. Sunnotel O, Hiripi L, Lagan K et al (2010) Alterations in the steroid hormone receptor co-chaperone FKBPL are associated with male infertility: a casecontrol study. Reprod Biol Endocrinol. 8:22. https://doi.org/10.1186/14777827-8-22

55. Ketefian A, Jones MR, Krauss RM. Association study of androgen signaling pathway genes in polycystic ovary syndrome. Fertil Steril. 2016; 105(2):46773.e4. DOI: 10.1016/j.fertnstert.2015;09: 043.

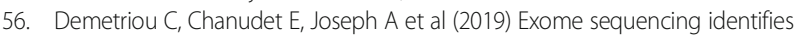
variants in FKBP4 that are associated with recurrent fetal loss in humans. Hum Mol Genet. 28(20):3466-3474. https://doi.org/10.1093/hmg/ddz203 
57. Ditton HJ, Zimmer J, Kamp C, Rajpert-De ME, Vogt PH (2004) The AZFa gene DBY (DDX3Y) is widely transcribed but the protein is limited to the male germ cells by translation control. Hum Mol Genet. 13(19):2333-2341. https://doi.org/10.1093/hmg/ddh240

58. Luddi A, Margollicci M, Gambera L et al (2009) Spermatogenesis in a man with complete deletion of USP9Y.N. Engl J Med. 360(9):881-885. https://doi. org/10.1056/NEJMoa0806218

59. Uniport. 2020. UniProtKB - 000507 (USP9Y_HUMAN). Available at https:// www.uniprot.org/uniprot/O00507.

60. Habedanck R, Stierhof YD, Wilkinson CJ, Nigg EA (2005) The Polo kinase PIk4 functions in centriole duplication. Nat Cell Biol. 7:1140-1146. https://doi.org/ 10.1038/ncb1320

61. GeneCards. 2020. PLK4 Gene. Available at https://www.genecards.org/cgibin/carddisp.pl?gene=PLK4.

62. Harris RM, Weiss J, Jameson JL (2011) Male hypogonadism and germ cell loss caused by a mutation in Polo-like kinase 4. Endocrinol. 152:3975-3985. https://doi.org/10.1210/en.2011-1106

63. Miyamoto T, Minase G, Shin T, Ueda H, Okada H, Sengoku K (2017) Human male infertility and its genetic causes. Reprod Med Biol. 16(2):81-88. https:// doi.org/10.1002/rmb2.12017

64. Veleri S, Bishop K, Dalle Nogare DE et al (2012) Knockdown of Bardet-Biedl syndrome gene BBS9/PTHB1 leads to cilia defects. PLoS ONE. 7(3):e34389. https://doi.org/10.1371/journal.pone.0034389

65. HyunJun K, Seung KL, Min-Ho K et al (2008) Parathyroid hormoneresponsive $\mathrm{B} 1$ gene is associated with premature ovarian failure. Hum Reprod. 23(6):1457-1465. https://doi.org/10.1093/humrep/den086

66. Genetic Home Reference. 2020. FSHR gene. Available at https://ghr.nlm.nih. gov/gene/FSHR\#location. .

67. Aittomäki K, Lucena JD, Pakarinen P et al (1995) Mutation in the folliclestimulating hormone receptor gene causes hereditary hypergonadotropic ovarian failure. Cell. 82(6):959-968 https://doi.org/10.1016/00928674(95)90275-9

68. Uniport. 2020. UniProtKB - P23945 (FSHR_HUMAN). Available at https:// www.uniprot.org/uniprot/P23945.

69. Miyamoto T, Tsujimura A, Miyagawa Y, Koh E, Namiki SK. Male infertility and its causes in human. Adv Urol. 2012; Article ID 384520. DOI: 10.1155/ 2012/384520.

70. Uniport. 2020. UniProtKB - Q9BXB7 (SPT16_HUMAN). Available at https:// www.uniprot.org/uniprot/Q9BXB7. Accessed 23 march, 2020.

71. Dam AH, Koscinski I, Kremer JA et al (2007) Homozygous mutation in SPAT A16 is associated with male infertility in human globozoospermia. Am J Hum Genet. 81(4):813-820. https://doi.org/10.1086/521314

72. Genetic Home Reference. 2020. AURKC gene. Available at https://ghr.nlm. nih.gov/gene/AURKC.

73. Genetic Home Reference. 2020. CATSPER1 gene. Available at https://ghr. nlm.nih.gov/gene/CATSPER1\#location. .

74. Avenarius MR, Hildebrand MS, Zhang Y et al (2009) Human male infertility caused by mutations in the CATSPER1 channel protein. Am J Hum Gen. 84(4):505-510 https://doi.org/10.1016/j.ajhg.2009.03.004

75. Nuti F, Krausz C (2008) Gene polymorphisms/mutations relevant to abnormal spermatogenesis. Reprod Biomed Online. 16:504-513. https://doi. org/10.1016/s1472-6483(10)60457-9

76. Genetic Home Reference. 2020. MTHFR gene. Available at https://ghr.nlm. nih.gov/gene/MTHFR\#normalfunction. Accessed March, 2020.

77. Friedman G, Goldschmidt N, Friedlander $Y$ et al (1999) A common mutation A1298C in human methylenetetrahydrofolate reductase gene: association with plasma total homocysteine and folate concentrations. J Nutr. 129: 1656-1661. https://doi.org/10.1093/jn/129.9.1656

78. Marques CJ, Costa P, Vaz B et al (2008) Abnormal methylation of imprinted genes in human sperm is associated with oligozoospermia. Mol Hum Reprod. 14:67-74. https://doi.org/10.1093/molehr/gam093

79. National Center for Biotechnology Information. 2020. SYCP3 synaptonemal complex protein 3 [Homo sapiens (human)]. Available at https://www.ncbi. nlm.nih.gov/gene/50511. .

80. Uniport. 2020. UniProtKB - Q8IZU3 (SYCP3_HUMAN). Available at https:// www.uniprot.org/uniprot/Q8IZU3. .

81. GeneCards. 2020. HSF2 Gene. Available at https://www.genecards.org/cgibin/carddisp.pl?gene=HSF2.

82. Mou L, Wang Y, Li H et al (2013) A dominant-negative mutation of HSF2 associated with idiopathic azoospermia. Hum Genet. 132(2):159-165
83. Wang G, Ying Z, Jin X et al (2004) Essential requirement for both hsf1 and hsf2 transcriptional activity in spermatogenesis and male fertility. Genesis. 38(2):66-80. https://doi.org/10.1002/gene.20005

84. GeneCards. 2020. SYCP2 Gene. Available at https://www.genecards.org/cgibin/carddisp.pl?gene=SYCP2. .

85. Schilit SLP, Menon S, Friedrich C et al (2020) SYCP2 translocation-mediated dysregulation and frameshift variants cause human male infertility. Am J Hum Genet. 6(1):41-57. https://doi.org/10.1016/j.ajhg.2019.11.013

86. Takemoto K, Imai Y, Saito K et al (2020) Sycp2 is essential for synaptonemal complex assembly, early meiotic recombination and homologous pairing in zebrafish spermatocytes. PLoS Genet. 16(2):e1008640. https://doi.org/10. 1371/journal.pgen.1008640

87. Bolcun-Filas E, Bannister LA, Barash A et al (2011) A-MYB (MYBL1) transcription factor is a master regulator of male meiosis. Develop. 138: 3319-3330. https://doi.org/10.1242/dev.067645

88. Yang F, Silber S, Leu NA. TEX11 is mutated in infertile men with azoospermia and regulates genome-wide recombination rates in mouse. EMBO Mol Med. 2015; 7(9):1198-1210. doi:10.15252/emmm.201404967.

89. Uniport. 2020. UniProtKB - Q8IYF3 (TEX11_HUMAN). Available at https:// www.uniprot.org/uniprot/Q8IYF3. .

90. Genetic Home Reference. 2020. KIT gene. Available at https://ghr.nlm.nih. gov/gene/KIT\#conditions.

91. Lars R, Johan L (2016) KIT (v-kit Hardy-Zuckerman 4 feline sarcoma viral oncogene homolog). Atlas Genet Cytogenet Oncol Haematol. 20(8):441-444 http://atlasgeneticsoncology.org/Genes/KITID127.html

92. Uniport. 2020. UniProtKB - Q8IZP9 (AGRG2_HUMAN). Available at https:// www.uniprot.org/uniprot/Q8IZP9. .

93. Patat O, Pagin A, Siegfried A et al (2016) Truncating mutations in the adhesion G protein-coupled receptor G2 gene ADGRG2 cause an X-linked congenital bilateral absence of vas deferens. Am J Hum Genet. 99(2):437442. https://doi.org/10.1016/j.ajhg.2016.06.012

94. National Center for Biotechnology Information. 2020. FKBP6 FKBP prolyl isomerase 6 [Homo sapiens (human)]. Available at https://www.ncbi.nlm.nih. gov/gene/8468.

95. Crackower MA, Kolas NK, Noguchi J (2003) Essential role of Fkbp6 in male fertility and homologous chromosome pairing in meiosis. Science. 300(5623):1291-1295. https://doi.org/10.1126/science.1083022

96. Uniport. 2020. UniProtKB - O75344 (FKBP6_HUMAN). Available at https:// www.uniprot.org/uniprot/075344.

97. Akmal M, Aulanni'am A, Widodo MA, Sumitro SB, Purnomo BB (2016) The important role of protamine in spermatogenesis and quality of sperm: a mini review. Asian Pac J Reprod. 5:357-360. https://doi.org/10.1016/j.apjr. 2016.07.013

98. Ravel C, Chantot-Bastaraud S, El Houate B et al (2007) Mutations in the protamine 1 gene associated with male infertility. Mol Hum Reprod. 13(7): 461-464. https://doi.org/10.1093/molehr/gam031

99. Jiang W, Sun H, Zhang J (2005) Polymorphisms in protamine 1 and protamine 2 predict the risk of male infertility: a meta-analysis. Sci Rep. 5 : 15300. https://doi.org/10.1038/srep15300

100. Siasi E, Aleyasin A, Mowla J, Sahebkasha H (2012) Association study of six SNPs in PRM1, PRM2 and TNP2 genes in iranian infertile men with idiopathic azoospermia. Iran J Reprod Med. 10:329-336

101. Miyagawa Y, Nishimura H, Tsujimura A et al (2005) Single-nucleotide polymorphisms and mutation analyses of the TNP1 and TNP2 genes of fertile and infertile human male. J Androl. 26(6):779-786. https://doi.org/10. 2164/jandrol.05069

102. Heidari MM, Khatami M, Talebi AR, Moezzi F. Mutation analysis of TNP1 gene in infertile men with varicocele. Iran J Reprod Med. 2014; 12(4):257-62. .

103. Adham IM, Nayernia K, Burkhardt-Göttges E et al (2001) Teratozoospermia in mice lacking the transition protein 2 (Tnp2). Mol Hum Reprod. 7(6):513-520. https://doi.org/10.1093/molehr/7.6.513

104. Uniport. 2020. UniProtKB - Q9NQZ3 (DAZ1_HUMAN). Available at https:// www.uniprot.org/uniprot/Q9NQZ3.

105. Fernandes K, Huellen J, Goncalves H et al (2002) High frequency of DAZ1/ DAZ2 gene deletions in patients with severeoligozoospermia. Mol Hum Reprod. 8(3):286-298. https://doi.org/10.1093/molehr/8.3.286

106. Genetic Home Reference. 2020. DAZI gene. Available at https://ghr.nIm.nih. gov/gene/DAZ1.

107. Deans B, Griffin CS, Maconochie M, Thacker J (2000) Xrcc2 is required for genetic stability, embryonic neurogenesis and viability in mice. EMBO J. 19(24):6675-6685. https://doi.org/10.1093/emboj/19.24.6675 
108. Yang Y, Guo J, Dai L (2018) XRCC2 mutation causes meiotic arrest, azoospermia and infertility. J Med Genet. 55:628-636. https://doi.org/10. 1136/jmedgenet-2017-105145

109. GeneCards. 2020. CCDC62 Gene. Available at https://www.genecards.org/ cgi-bin/carddisp.pl?gene=CCDC62. .

110. Li Y, Li C, Lin S et al (2017) A nonsense mutation in Ccdc62 gene is responsible for spermiogenesis defects and male infertility in repro29/repro29 mice. Biol Reprod. 96(3):587-597 https://doi.org/10.1095/biolreprod.116.141408

111. Hwang JY, Mannowetz N, Zhang Y. EFCAB9 is a pH-Dependent Ca2+ sensor that regulates CatSper channel activity and sperm motility. BioRxiv. 2018; Article no 459487. doi: https://doi.org/10.1101/459487.

112. Yatsenko AN, Roy A, Chen R (2006) Non-invasive genetic diagnosis of male infertility using spermatozoal RNA: KLHL10 mutations in oligozoospermic patients impair homodimerization. Hum Mol Genet. 15:3411-3419. https:// doi.org/10.1093/hmg/ddl417

113. Kuo YC, Lin YH, Chen HI et al (2012) SEPT12 mutations cause male infertility with defective sperm annulus. Hum Mutat. 33:710-719. https://doi.org/10. 1002/humu.22028

114. Uniport. 2020. UniProtKB - Q92750 (TAF4B_HUMAN). Available at https:// www.uniprot.org/uniprot/Q92750. .

115. Ayhan Ö, Balkan M, Guven A et al (2014) Truncating mutations in TAF4B and ZMYND15 causing recessive azoospermia. J Med Genet. 51:239-244. https://doi.org/10.1136/jmedgenet-2013-102102

116. Yan W, Si Y, Slaymaker S et al (2010) Zmynd15 encodes a histone deacetylase-dependent transcriptional repressor essential for spermiogenesis and male fertility. J Biol Chem. 285:31418-31426. https:// doi.org/10.1074/jbc.M110.116418

117. Uniport. 2020. UniProtKB - Q9H091 (ZMY15_HUMAN). Available at https:// www.uniprot.org/uniprot/Q9H091.

118. National Center for Biotechnology Information. 2020. NANOS1 nanos C2HCtype zinc finger 1 [Homo sapiens (human)]. Available at https://www.ncbi. nlm.nih.gov/gene/340719.

119. Kusz-Zamelczyk K, Sajek M, Spik A (2013) Mutations of NANOS1, a human homologue of the Drosophila morphogen, are associated with a lack of germ cells in testes or severe oligo-astheno-teratozoospermia. J Med Genet. 50:187-193. https://doi.org/10.1136/jmedgenet-2012-101230

120. Uniport. 2020. UniProtKB - Q8WY41 (NANO1_HUMAN). Available at https:// www.uniprot.org/uniprot/Q8WY41.

121. Uniport. 2020. UniProtKB - Q7Z4T8 (GLTL5_HUMAN). Available at https:// www.uniprot.org/uniprot/Q7Z4T8. .

122. Takasaki N, Tachibana K, Ogasawara S (2014) A heterozygous mutation of GALNTL5 affects male infertility with impairment of sperm motility. Proc Natl Acad Sci USA. 111:1120-1125. https://doi.org/10.1073/pnas.1310777111

123. National Center for Biotechnology Information. 2020. GNRHR gonadotropin releasing hormone receptor [Homo sapiens (human)]. Available at https:// www.ncbi.nlm.nih.gov/gene/2798. .

124. Zernov N, Skoblov M, Baranova A, Boyarsky K (2016) Mutations in gonadotropin-releasing hormone signaling pathway in two $\mathrm{nlHH}$ patients with successful pregnancy outcomes. Reprod Biol Endocrinol. 14:48. https:// doi.org/10.1186/s12958-016-0183-8

125. Uniport. 2020. UniProtKB - P30968 (GNRHR_HUMAN). Available at https:// www.uniprot.org/uniprot/P30968.

126. Genetic Home Reference. 2020. PROP1 gene. Available at https://ghr.nlm. nih.gov/gene/PROP1\#location. .

127. Uniport (2020) UniProtKB - Q9Y5R6 (DMRT1_HUMAN). Available at https:// www.uniprot.org/uniprot/Q9Y5R6.Accessed (March 25, 2020)

128. Uniport. 2020. UniProtKB - P41225 (SOX3_HUMAN). Available at https:// www.uniprot.org/uniprot/P41225. .

129. Uniport. 2020. UniProtKB - Q2MKA7 (RSPO1_HUMAN). Available at https:// www.uniprot.org/uniprot/Q2MKA7.

130. Tomaselli S, Megiorni F, De Bernardo C et al (2007) Syndromic true hermaphroditism due to an R-spondin1 (RSPO1) homozygous mutation. Human Mutat. 29(2):220-226. https://doi.org/10.1002/humu.20665

131. National Center for Biotechnology Information. 2020. BMP15 bone morphogenetic protein 15 [Homo sapiens (human)]. Available at https:// www.ncbi.n/m.nih.gov/gene/9210.

132. Uniport. 2020. UniProtKB - 095972 (BMP15_HUMAN). Available at https:// www.uniprot.org/uniprot/095972.

133. National Center for Biotechnology Information. 2020. FIGLA folliculogenesis specific bHLH transcription factor [Homo sapiens (human)]. Available at https://www.ncbi.nlm.nih.gov/gene/344018. .
134. Zhao H, Chen ZJ, Qin Y et al (2008) Transcription factor FIGLA is mutated in patients with premature ovarian failure. Am J Hum Genet. 82(6):1342-1348. https://doi.org/10.1016/j.ajhg.2008.04.018

135. Soyal SM, Amleh A, Dean J (2000) FIGalpha. A germ cell-specific transcription factor required for ovarian follicle formation. Develop. 127(21):4645-4654

136. Uniport. 2020. UniProtKB - Q6QHK4 (FIGLA_HUMAN). Available at https:// wWw.uniprot.org/uniprot/Q6QHK4.

137. Rajkovic A, Pangas SA, Ballow D, Suzumori N, Matzuk MM (2004) NOBOX deficiency disrupts early folliculogenesis and oocyte-specific gene expression. Science. 305(5687):1157-1159. https://doi.org/10.1126/ science. 1099755

138. Bouilly J, Bachelot A, Broutin I, Touraine P, Binart N (2011) Novel NOBOX loss-of-function mutations account for $6.2 \%$ of cases in a large primary ovarian insufficiency cohort. Hum Mutat. 32(10):1108-1113. https://doi.org/ 10.1002/humu.21543

139. Qin Y, Choi Y, Zhao H, Simpson JL, Chen ZJ, Rajkovic A (2007) NOBOX homeobox mutation causes premature ovarian failure. Am J Hum Genet. 81(3):576-581. https://doi.org/10.1086/519496

140. Tahara N, Kawakami H, Zhang T et al (2018) Temporal changes of Sall4 lineage contribution in developing embryos and the contribution of Sall4lineages to postnatal germ cells in mice. Sci Rep. 8:16410 https://doi.org/10. 1038/s41598-018-34745-5

141. Wang B, Li L, Ni F (2009) Mutational analysis of SAL-Like 4 (SALL4) in Han Chinese women with premature ovarian failure. Mol Hum Reprod. 15(9): 557-562. https://doi.org/10.1093/molehr/gap046

142. GeneCards. 2020. FSHB Gene. Available at https://www.genecards.org/cgibin/carddisp.pl?gene=FSHB\#summaries. .

143. Layman LC, Lee EJ, Peak DB (1997) Delayed puberty and hypogonadism caused by a mutation in the follicle stimulating hormone $\beta$-subunit gene. $N$ Engl J Med. 337:607-611

144. Rull1 K, Laan M. Expression of $\beta$-subunit of human chorionic gonadotropin genes during the normal and failed pregnancy. Hum Reprod. 2005; 20(12): 3360-3368. doi: https://doi.org/10.1093/humrep/dei261.

145. Nagirnaja L, Venclovas C, Rull K et al (2012) Structural and functional analysis of rare missense mutations in human chorionic gonadotrophin $\beta$-subunit. Mol Hum Reprod. 18(8):379-390. https://doi.org/10.1093/molehr/gas018

146. Poikkeus P, Hiilesmaa $V$, Tiitinen A (2002) Serum HCG 12 days after embryo transfer in predicting pregnancy outcome. Hum Reprod. 17:1901-1905. https://doi.org/10.1093/humrep/17.7.1901

147. ational Center for Biotechnology Information. 2020. SOHLH1 spermatogenesis and oogenesis specific basic helix-loop-helix 1 [Homo sapiens (human)]. Available at https://www.ncbi.nlm.nih.gov/gene/402381.

148. Uniport. 2020. UniProtKB - Q5JUK2 (SOLH1_HUMAN). Available at https:// wWw.uniprot.org/uniprot/Q5JUK2.

149. Toyoda S, Yoshimura T, Mizuta J, J-i M (2014) Auto-regulation of the Sohlh1 gene by the SOHLH2/SOHLH1/SP1 complex: implications for early spermatogenesis and oogenesis. PLoS ONE. 9(7):e101681. https://doi.org/10. 1371/journal.pone.0101681

150. Shin YH, Ren Y, Suzuki H et al (2017) Transcription factors SOHLH1 and SOHLH2 coordinate oocyte differentiation without affecting meiosis I. J Clin Invest. 127(6):2106-2211. https://doi.org/10.1172/JCl90281

151. Qin Y, Jiao X, Dalgleish R et al (2014) Novel variants in the SOHLH2 gene are implicated in human premature ovarian failure. Fertil Steril. 101(4):11041109. https://doi.org/10.1016/j.fertnstert.2014.01.001

152. Song B, Zhang Y, He XJ et al (2015) Association of genetic variants in SOHLH1 and $\mathrm{SOHLH} 2$ with non-obstructive azoospermia risk in the Chinese population. Eur J Obstet Gynecol Reprod Biol. 184:48-52. https://doi.org/10. 1016/j.ejogrb.2014.11.003

153. Hao J, Yamamoto M, Richardson TE et al (2008) Sohlh2 knockout mice are male-sterile because of degeneration of differentiating type $A$ spermatogonia. Stem Cells 26(6):1587-1597

154. Wu X, Thomas P, Yong ZY (2018) Pgrmc1 Knockout impairs oocyte maturation in zebrafish. Front.Endocrinol. 9:560. https://doi.org/10.3389/ fendo.2018.00560

155. Paskulin DD, Cunha-Filho JS, Paskulin LD, Souza CAB, Ashton-Prolla P (2013) ESR1 rs9340799 is associated with endometriosis-related infertility and in vitro fertilization failure. Disease Markers. 35(6):907-913. https://doi.org/10. 1155/2013/796290

156. Manosalva I, González A, Kageyama R (2013) Hes1 in the somatic cells of the murine ovary is necessary for oocyte survival and maturation. Develop Biol. 375(2):140-151. https://doi.org/10.1016/j.ydbio.2012.12.015 
157. Cariati F, D'Argenio V, Tomaiuolo R (2019) The evolving role of genetic tests in reproductive medicine. J Transl Med. 17:267. https://doi.org/10.1186/ s12967-019-2019-8

158. Devine K, Roth L. 2020. Genetic testing of embryos. Shady grove fertility. Available at https://www.shadygrovefertility.com/treatments-success/ advanced-treatments/genetic-testing-embryos.

159. Treff NR, Fedick A, Tao X, Devkota B, Taylor D, Scott RT (2013) Evaluation of targeted next-generation sequencing-based preimplantation genetic diagnosis of monogenic disease. Fertil Steril. 99:1377-1384. https://doi.org/ 10.1016/j.fertnstert.2012.12.018

\section{Publisher's Note}

Springer Nature remains neutral with regard to jurisdictional claims in published maps and institutional affiliations.

\section{Submit your manuscript to a SpringerOpen ${ }^{\circ}$ journal and benefit from:}

- Convenient online submission

- Rigorous peer review

- Open access: articles freely available online

- High visibility within the field

- Retaining the copyright to your article

Submit your next manuscript at $\boldsymbol{\nabla}$ springeropen.com 